\title{
MULTIPLE SCLEROSIS OR FABRY DISEASE - PROS AND CONS
}

\author{
Iris Zavoreo, Miljenka-Jelena Jurašić, Marijana Lisak, Ana Jadrijević Tomas and Vanja Bašić Kes
}

Department of Neurology, Sestre milosrdnice University Hospital Centre, Zagreb, Croatia

\begin{abstract}
SUMMARY - Fabry disease is a rare X-linked inherited lysosomal storage disease affecting multiple organ systems, presenting in the central nervous system (CNS) as white matter lesions with underlying cerebral vasculopathy and autoinflammatory changes of the choroid plexus and leptomeninges. We present a young female patient (age 36 years) admitted to our department due to visual loss on the left eye. Magnetic resonance imaging (MRI) showed demyelinating lesions in the frontal and parietal lobe, periventricularly, in mesencephalon and right cerebellar hemisphere, and left optic neuritis; MR angiography was normal. Her medical history revealed renal dysfunction, hypothyroidism, and miscarriage in the $6^{\text {th }}$ month of pregnancy due to eclampsia and Fabry disease in the family (mother). Cerebrospinal fluid analysis showed mild pleocytosis, normal blood brain barrier function and oligoclonal bands type 3. Visual evoked potentials showed prechiasmal dysfunction of the left optic nerve. Genetical testing for Fabry disease was positive (two heterozygous mutations), with decreased alpha galactosidase activity values and increased Lyso GB3 values. The patient received corticosteroid therapy (methylprednisolone) $1 \mathrm{~g}$ for 5 days, which led to regression of visual disturbances on the left eye. After this acute treatment, there was a question of definitive diagnosis and further treatment of the underlying cause. Considering renal dysfunction, miscarriage, arterial hypertension, positive genetic and biochemical testing for Fabry disease, as well as MRI findings showing lesions in posterior circulation, we concluded that the patient probably had Fabry disease with autoinflammatory changes in the CNS and should be treated with enzyme replacement therapy. Still, there was a question of optic neuritis on the left eye and positive oligoclonal bands favoring the diagnosis of multiple sclerosis. Therefore, further clinical and neuroradiological follow up was needed to distinguish multiple sclerosis and Fabry disease in this patient.
\end{abstract}

Key words: Fabry disease; Multiple sclerosis - therapy; Croatia; Case reports

\section{Introduction}

Fabry disease is an $\mathrm{X}$-linked inherited lysosomal storage disease caused by mutations (or alterations) in the a-Gal A (GLA) gene that result in insufficient activity of the a-Gal A enzyme. Lysosomes are primary digestive units within cells, therefore they are enriched with enzymes which break down or digest particular compounds and intracellular structures. The function

Correspondence to: Assist. Prof. Iris Zavoreo, $M D, P h D$, Department of Neurology, Sestre milosrdnice University Hospital Centre, Vinogradska c. 29, HR-10000 Zagreb, Croatia

E-mail: iris_zavoreo@yahoo.com

Received November 21, 2016, accepted December 28, 2016 of the GLA enzymes is to break down globotriaosylceramide (GL-3 or Gb3), lyso-GL-3/Gb3 and related glycolipids by removing terminal galactose sugar from the end of these glycolipid molecules. The enzyme deficiency causes continuous build-up of GL-3/Gb3 and related glycolipids in the body cells, resulting in cell abnormalities and organ dysfunction ${ }^{1-3}$. Due to Xlinked inheritance pattern, males are typically more severely affected than females. Females have a more variable course and may be asymptomatic or as severely affected as males due to so-called lyonization, i.e. females have two copies of the $\mathrm{X}$ chromosome, one of which is inactivated randomly, thus they have no phenotypic expression. Therefore, there is always lower 
GLA enzyme level in plasma, while in females GLA enzyme activity levels depend not only on GLA mutations of the $\mathrm{X}$ chromosome, but also on the lyonization effect ${ }^{4,5}$.

Fabry disease is estimated to affect 1 in 40,000 to 60,000 males. This disorder also occurs in females, although the prevalence is unknown. Milder, late-onset forms of the disorder are probably more common than the classic, severe form. The average age at diagnosis is approximately 30 years. Delayed diagnosis may be due to the rarity of the disease and/or the nonspecific nature of its early symptoms $s^{6,7}$.

There are two major disease phenotypes, i.e. type 1 'classic' and type 1 'later-onset' subtypes. The signs and symptoms of classic phenotype typically begin in childhood or adolescence. Symptoms increase with age due to the progressive glycolipid accumulation in the vascular system, kidneys and heart leading to kidney failure, heart disease or strokes. Early and progressive clinical symptoms include acroparesthesias, anhidrosis or hypohidrosis, angiokeratomas, gastrointestinal problems, and corneal dystrophy. Additional symptoms include chronic fatigue, dizziness, headache, generalized weakness, nausea, vomiting, delayed puberty, lack of or sparse hair growth, and rarely malformation of the joints of the fingers.

Involvement of the central nervous system (CNS) in Fabry disease patients is mainly due to cerebral vasculopathy affecting both small and large cerebral vessels. Macroangiopathy usually leads to ischemic stroke, while microangiopathy is usually the cause of progressive white matter lesions confirmed by magnetic resonance imaging (MRI) in about $80 \%$ of Fabry disease patients (both genders). Because of its clinical presentation, as well as previously mentioned MRI findings, Fabry disease takes an important place in the differential diagnosis of multiple sclerosis (MS). Clinicians should be extremely careful in establishing diagnosis in patients with Fabry disease because intermittent Fabry symptoms can be misleading and patient can fulfill Mc Donald criteria for MS, as well as aberrations in cerebrospinal fluid finding suggesting $\mathrm{MS}^{8,9}$.

\section{Case Report}

We present a young female patient (age 36 years) admitted to our department due to visual loss on the left eye. MRI showed demyelinating lesions in the frontal and parietal lobe, periventricularly, in mesencephalon and right cerebelar hemisphere, and left optic neuritis; MR angiography was normal. The patient's history revealed renal dysfunction, hypothyroidism, and miscarriage in the $6^{\text {th }}$ month of pregnancy due to eclampsia and genetically confirmed Fabry disease in the family (mother and one sister). Cerebrospinal fluid analysis showed mild pleocytosis, normal blood brain barrier function, and oligoclonal bands type 3 . Visual evoked potentials showed prechiasmal dysfunction of the left optic nerve. Genetic testing for Fabry disease was positive (two heterozygous mutations), with decreased alpha galactosidase activity values and increased Lyso GB3 values. Neurological examination showed loss of visual acuity on the left eye, without any other neurological signs and symptoms.

The patient received corticosteroid therapy (methylprednisolone) $1 \mathrm{~g}$ for 5 days, which led to regression of visual disturbances on the left eye.

After this acute treatment, there was a question of definitive diagnosis and further treatment of the underlying cause. Considering renal dysfunction, miscarriage, arterial hypertension, positive genetic and biochemical testing for Fabry disease, as well as MRI findings showing lesions in posterior circulation (Figs. 1-4), we concluded that the patient probably had Fabry disease with microangiopathy complications (autoinflammatory vasculopathy) of the brain white matter, which required treatment with enzyme replacement therapy. Still, there was a question of optic neuritis of the left eye and positive oligoclonal bands favoring the diagnosis of MS. Therefore, further clinical and neuroradiological follow up was needed to distinguish MS and Fabry disease in this patient.

\section{Discussion}

Fabry disease affects young people and can have monosymptomatic courses, which only involve CNS without any medical history of other classic Fabry symptoms such as angiokeratoma, cornea veriticillata, or heart and kidney disease. MS is one of the most common neurologic diseases in young population of Western countries. Differential diagnosis of MS requires detailed workup to exclude any other inflammatory or non-inflammatory brain white matter diseases mimicking clinical and/or MRI features of MS. Overpresentation or intermittent presentation of cerebellar 


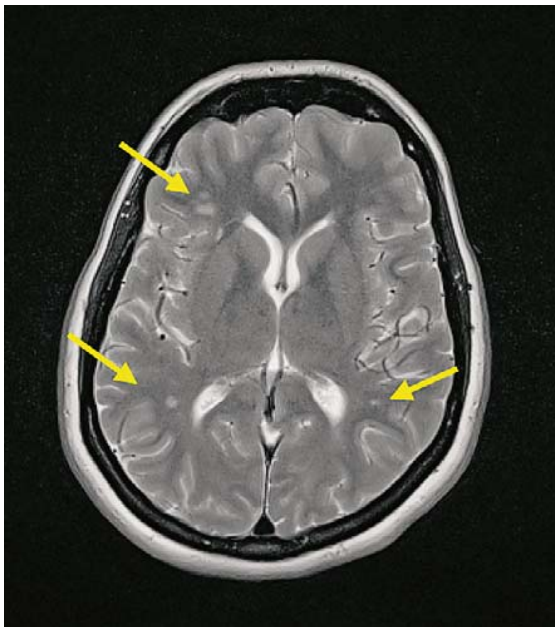

Fig. 1. Horizontal T2 MRI section: multiple demyelinating lesions.

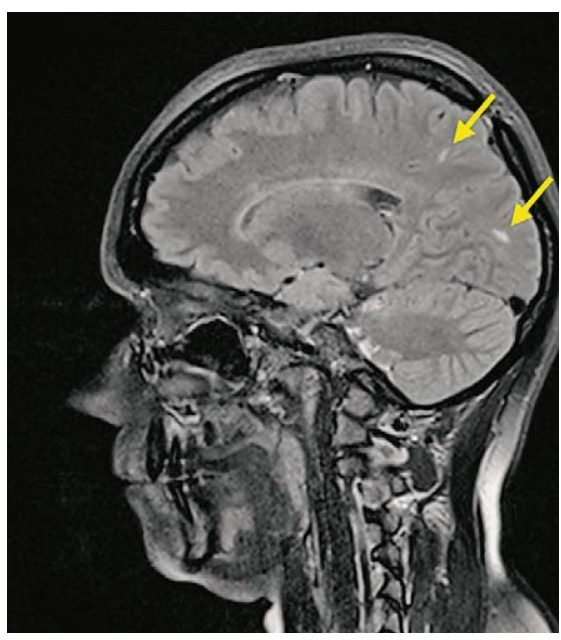

Fig. 3. Sagittal T1 MRI section: multiple demyelinating lesions.

and/or brain stem symptoms (ataxia, gait disturbances, double vision, vertigo, posterior vascular territory symptoms) in combination with sensory deficits due to small fiber lesions, as well as white matter lesions on MRI, can mislead clinicians in establishing diagnosis of MS according to temporal and space dissemination. Usually MRI of the cervical spinal cord is not performed in Fabry patients, and lesions at these locations are probably underestimated. In most cases, there are no white matter lesions in the spinal cord in Fabry patients, which can be one of the distinguishing parameters 9 . Changes in the cerebrospinal fluid are also present in Fabry patients and are defined as 'aseptic men-

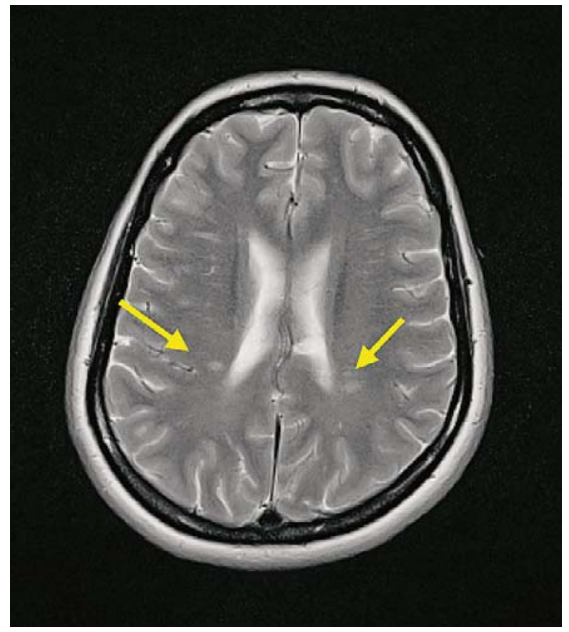

Fig. 2. Horizontal T2 MRI section: multiple demyelinating lesions.

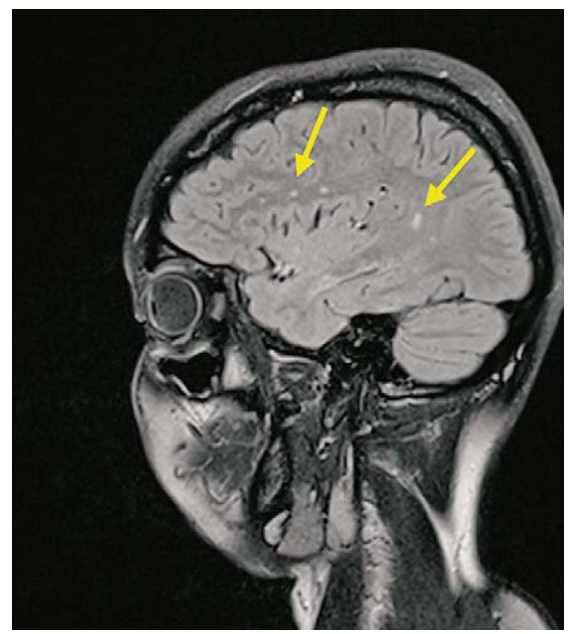

Fig. 4. Sagittal T1 MRI section: multiple demyelinating lesions.

ingitis' or chronic meningitis with mild to moderate pleocytosis (76 cells $/ \mu \mathrm{L})$ and slightly elevated total protein levels (up to $800 \mathrm{mg} / \mathrm{L}$ ) suggesting disturbed blood brain barrier function, mostly with lymphomonocytic response. Results of the postmortem studies showed high accumulation of ceramide trihexosides in the choroid plexus and leptomeninges in one Fabry patient. These findings suggest an aseptic inflammatory process triggered by the stored lipids acting as foreign body stimulus. Oligoclonal bands can also be positive in cerebrospinal fluid of Fabry patients, they have high sensitivity in MS patients, but they also are highly unspecific and can occur even after unspe- 
cific infections. Establishing diagnosis of Fabry disease is challenging, especially in patients without non-neurologic manifestations of Fabry disease. According to previous studies, Fabry diagnosis should be considered in female patients with asymmetric, confluent white matter lesions on MRI without or with very mild corpus callosum T1 hyperintensities and/or lack of gadolinium enhancement and/or normal spinal MRI, ectatic vertebrobasilar arteries, and/or negative oligoclonal bands, significant proteinuria or unexplained left ventricular hyperthrophy, and a relative that died at a young age from unspecified renal, cardiac or cerebrovascular disease $(\mathrm{X} \text {-linked })^{10,11}$

Establishing an accurate diagnosis in the early stages of both Fabry disease and MS is of great importance in planning long term treatment which will cure symptoms and underlying condition, while preventing organ damage and disabilities. In Fabry patients, enzyme replacement therapy has shown good results in disease control. In MS, there are numerous possibilities of acute treatment, as well as immunomodulatory therapy. Therefore, an accurate and timely diagnosis (in early stages of the disease if possible) is the best prognostic factor for successful disease control ${ }^{8}$.

\section{References}

1. Tuttolomondo A, Pecoraro R, Simonetta I, Miceli S, Pinto A, Licata G. Anderson-Fabry disease: a multiorgan disease. Curr Pharm Des. 2013;19(33):5974-96.

2. Tuttolomondo A, Pecoraro R, Simonetta I, Miceli S, Arnao V, Licata G, Pinto A. Neurological complications of AndersonFabry disease. Curr Pharm Des. 2013;19(33):6014-30.
3. Ries M, Ramaswami U. The early clinical phenotype of Fabry disease: a study of 35 European children. Eur J Pediatr 2003; 162:767-72. DOI: $10.1007 / \mathrm{s} 00431-003-1299-3$

4. Mehta A, Beck M, Sunder-Plassmann G. Fabry disease: perspectives from 5 years of FOS. Oxford PharmaGenesis Ltd., England, 2006.

5. Nakao S, Kodama C, Takenaka T, et al. Fabry disease: detection of undiagnosed hemodialysis patients and identification of a "renal variant" phenotype. Kidney Int. 2003;64: 801-7. DOI: 10.1046/j.1523-1755.2003.00160.x

6. Salviati A, Burlina AP, Borsini W. Nervous system and Fabry disease, from symptoms to diagnosis: damage evaluation and follow-up in adult patients, enzyme replacement, and support therapy. Neurol Sci. 2010;31:299-306.

DOI: $10.1007 /$ s10072-009-0211-y

7. Germain DP. Fabry disease. Orphanet J Rare Dis. 2010;5:30. DOI: $10.1186 / 1750-1172-5-30$

8. Mehta A, Lewis S, Lavery C. Treatment of lysosomal storage disorders. BMJ. 2003;327:462-3.

DOI: $10.1136 /$ bmj.327.7413.462

9. Bašić Kes V, Cesarik M, Zavoreo I, Soldo-Butković S, Kes P, Bašić-Jukić N, Rački S, Jakić M, Delić-Brkljačić $D$, Jukić $Z$, Trkanjec Z, Šerić V, Vargek Solter V, Bielen I, Bašić S, Demarin V; Croatian Society for Neurovascular Disorders of Croatian Medical Association; Croatian Society of Neuroimmunology and Neurogenetics; Croatian Society of Neurology of Croatian Medical Association; Croatian Society of Nephrology, Dialysis and Transplantation of Croatian Medical Association. Guidelines for diagnosis, therapy and follow up of Anderson-Fabry disease. Acta Clin Croat. 2013;52(3):395-405.

10. Shribman SE, Shah AR, Werring DJ, Cockerell OC. Fabry disease mimicking multiple sclerosis: lessons from two case reports. Mult Scler Relat Disord. 2015;4(2):170-5. DOI: 10.1016/j.msard.2015.01.001

11. Böttcher T, Rolfs A, Tanislav C, Bitsch A, Köhler W, Gaedeke J, Giese AK, Kolodny EH, Duning T. Fabry disease - underestimated in the differential diagnosis of multiple sclerosis? PLoS One. 2013;8(8):e71894. DOI: 10.1371/journal.pone.0071894 


\title{
Sažetak
}

\section{MULTIPLA SKLEROZA ILI FABRIJEVA BOLEST - ZA I PROTIV}

\author{
I. Zavoreo, M. J. Jurašić, M. Lisak, A. Jadrijević Tomas i V. Bašić Kes
}

Fabryjeva bolest je rijetka $\mathrm{X}$ vezana lizosomska bolest nakupljanja koja zahvaća više organskih sustava u organizmu, a u središnjem živčanom sustavu (SŽS) se prezentira kao lezije bijele tvari koje su posljedica vaskulopatije i autoimunih procesa na razini koroidnog pleksusa. U radu se prikazuje slučaj mlade žene (36 godina) koja je primljena na našu Kliniku zbog poremećaja vida na lijevom oku. Nalaz magnetske rezonance (MR) mozga je pokazao demijelinizacijske lezije u frontalnom i parijetalnom režnju, periventrikularno, u mezencefalonu, desnoj hemisferi malog mozga te optički neuritis lijevo. Nalaz MR angiografije mozga je bio uredan. U osobnoj anamnezi se doznaje da se bolesnica liječila zbog bubrežne insuficijencije, hipotireoze te da je u 6. mjesecu trudnoće imala spontani pobačaj uslijed eklampsije. U obiteljskoj anamnezi se doznaje da majka boluje od Fabryjeve bolesti. U analizi cerebrospinalnog likvora nađe se blaga pleocitoza, uredna funkcija krvnomoždane barijere te sinteza IgG unutar SŽS-a, oligoklonske vrpce tip 3. Vidni evocirani potencijali pokazali su disfunkciju prekjazmalno lijevo. Genetsko testiranje na Fabryjevu bolest pokazalo je pozitivan nalaz, 2 heterozigotne mutacije, smanjenu aktivnost alfa galaktosidaze te povišene vrijednosti Lyso GB3. Bolesnica je primila pulsnu kortikosteroidnu terapiju (metilprednisolon $1 \mathrm{~g}$ ) kroz 5 dana, što je dovelo do regresije smetnji vida na lijevom oku. Nakon akutnog liječenja simptoma postavlja se pitanje konačne dijagnoze i dugoročnog liječenja. Uzimajući u obzir prisutnost bubrežne insuficijencije, eklampsiju u trudnoći uz spontani pobačaj, pozitivne rezultate genetskog testiranja i biokemijskih analiza za Fabryjevu bolest te nalaza MR mozga koji opisuje promjene dominantno u području stražnje cirkulacije zaključili smo da se u bolesnice najvjerojatnije radi o Fabryjevoj bolesti uz autoimune promjene u SŽS-u i da je bolesnicu potrebno liječiti enzimskom nadomjesnom terapijom. S obzirom na smetnje vida i nalaze pozitivnih oligoklonskih vrpci koji mogu govoriti i u prilog multiple skleroze potrebno je dalje pratiti bolesnicu klinički i neuroradiološki kako bi se postavila konačna dijagnoza.

Ključne riječi: Fabryjeva bolest; Multipla skleroza - terapija; Hrvatska; Prikazi slučaja 